\title{
Dominant Factors of Physical Ability Determining the Achievement of Artistic Gymnastic Techniques
}

\author{
Rifiy Qomarrullah', Agus Kristiyanto², Sugiharto $^{3}$, M. Furqon Hidayatullah ${ }^{4}$ \\ ${ }^{1}$ Graduate School, Universias Negeri Semarang (UNNES), Indonesia. \\ ${ }^{2,4}$ Graduate School, Universitas Sebelas Maret (UNS), Indonesia. \\ ${ }^{3}$ Department of Sport Science, UNNES, Indonesia. \\ ${ }^{1}$ Corresponding email: rifiy_qomarrullah@yahoo.co.id
}

\begin{abstract}
The vault tool in artistic gymnastics is a sport with high-performance parameters, and it belongs to anaerobic. The maximum technique achievement in the vault is strongly supported by elements of good physical performance. The study aims to analyze the relationship of physical ability factor of running speed, the strength of; leg muscle, arm muscle, abdominal muscle, and balance to the achievement of vault technique. The study involved 137 artistic gymnastics athletes aged 10 to 12 years who participated in the junior competition in Central Java Province Indonesia. The study consists of two stages: first, physical ability using $20 \mathrm{~m}$ run test, vertical jump, push-up, sit-up, static balance test; second, technical skills are obtained from forwarding handspring movements and round-off entries. Physical and technical capability data were collected twice, and the best score was taken. The data of the research were analyzed using SPSS AMOS 22.0. The results showed that the speed and running factor did not significantly influence; leg muscle strength factor, arm muscle strength, and abdominal muscle strength have a significant effect. The most dominant factor of physical achievement ability of vault technique is leg muscle strength, while the smallest influence is at run speed.
\end{abstract}

Keyword: physical ability; gymnastics; vault.

\section{Introduction}

Artistic Gymnastics is a competitive sport that requires high-performance parameters and is characterized by dynamism, rhythm, and spectacularity including acrobatic, beauty, and expressive (Mariana et al., 2016). The vault is one of the tools and is part of artistic gymnastics discipline; and its movement requires high performance and physical ability (Kochanowicz et al., 2016). The movements in the vault are seven phases: (1) run, (2) jump on springboard, (3) springboard support phase, 4) first flight phase, 5) support on the table, 6) second flight phase, and 7) landing (Atiković, 2012). Motion in the vault is classified as anaerobic because the dominant factors are an element of speed, and strength (Alves et al., 2015).

Physical exercise in every sport is the main foundation in the development of techniques, tactics and further mental (Pavlova et al., 2017; Subekti et al., 2014). All biomotor components must be developed to support athlete performance. Physical excellence for athletes will affect the mastery of the next exercise stage. However, the fact that happens in artistic gymnastics in Central Java Province is the pattern of training given by trainers which often leads directly to technical movement skills.

Documentation data owned by researchers showed that during the period of five times of conducting the national sporting event $(\mathrm{PON})$ in 2000, 2004, 2008, 2012, and 2016, every time the event was conducted, the artistic gymnastics trainers of jump table in Central Java only focus on technical training. Physical conditions have not been fostered maximally. This can be due to physical factors which are considered to have been represented during the exercise technique so that the physical condition automatically increases.

PON achievement data in 2000, 2004, 2008, 2012, and 2016 showed that artistic gymnastics tool vault team from Central Java team has no medal, meaning that the team never gets a champion. Referee judging data indicated that almost all the score reduction on the jump table tool is when the athlete makes a mistake in the phase of the leap to the first flight up to the second flight and the landing. This happens because of the incompetence of trainers in determining the formulation of exercise programs between physical exercise propositions, and technical training programs.

The research results by Akhtaruzzaman et al. (2016) showed that the lower limb in the 
leg supports superior parts: neck, head, and torso. Furthermore, Calatayud et al. (2014) stated that arm muscle strength contributes to the dominant upper extremity motion pattern. Therefore, it is necessary to research the dominant factors of physical ability of athletes that support technical achievements in general artistic gymnastics and vault tools specifically.

The purpose of this research is to analyze the relationship of physical ability factor of running speed, leg muscle strength, arm muscle strength, abdominal muscle strength, and balance to the performance of vault technique. This research is useful in the preparation of a proper physical exercise program to support the achievements of artistic gymnastics techniques of vault equipment at gymnastics clubs and sports extracurricular of school.

\section{Methods}

The subjects in this study were 137 junior athletes of artistic gymnastics from various gymnastics clubs and elementary school students aged 10 to 12 years old who participated in junior competition in Central Java Province Indonesia, with some considerations: 1) age 8 to 12 years is a phase of gymnastics training; 2) Selected physical abilities to become the basis for successful gymnasts from a young age; 3 ) in preparation for determining tactics and strategies towards PON XX in Papua Province in 2020. The research data was taken at the Laboratory Faculty of Sports Science of Universitas Negeri Semarang, on 27 - 28 November 2017. This study consists of two stages: taking physical capability data, and technical skills are implemented twice then the best score was chosen. Physical and technical capabilities data are performed on several test procedures and protocols as follows:

Physical ability tests include:Running speed test uses a 20 meter (m) run test on a straight line within as fast as possible time.

Leg muscle strength test uses a vertical test jump with a measuring scale of a centimeter $(\mathrm{cm})$. The arm muscle strength uses a push-up test, and during the execution of each subject, the research subject is given 1 minute.

Abdominal muscle strength test uses situp test, and each research subject is given 1 minute.
The balance test uses a static balance test. Each subject stands with one leg within 30 seconds. The test of technical skills used the technical guidance test of result-men for the vault, meaning that the gymnast performs handspring forward, and round off entry.

The hypothesis in this study is that there is significant factors between running speed (X1), leg muscle strength (X2), arm muscle strength (X3), abdominal muscle strength (X4), and balance (X5) on the achievement of vault technique (Y). Uglu (2013) stated that Hypothesis testing is done by using regression weights analysis and standardized regression weights to test the value of correlation factor obtained by using SOSS (Statistical Package for the Social Sciences) AMOS (Analysis of Moment Structures) 22.0 at significant level ( $\alpha$ $=0.05) \alpha=0.01$ ).

\section{Research Results}

\subsection{Results of Goodness of Fit}

An acceptable value index when performing structural model testing was listed in Table 1.

Table 1. Results of Goodness of Fit After Modification of the Model

\begin{tabular}{|c|c|c|c|c|}
\hline Goodness of Fit Index & $\begin{array}{l}\text { The } \\
\text { Expected } \\
\text { Score }\end{array}$ & $\begin{array}{l}\text { Results } \\
\text { before } \\
\text { Modificat } \\
\text { ion } \\
\end{array}$ & $\begin{array}{l}\text { Results } \\
\text { after } \\
\text { Modifi } \\
\text { cation } \\
\end{array}$ & $\begin{array}{l}\text { Evalua } \\
\text { tion of } \\
\text { Model }\end{array}$ \\
\hline (1) & (2) & (3) & (4) & $(5)$ \\
\hline Chi-Square $(\chi 2)$ & $\begin{array}{l}\mathrm{p}>0.05 \\
\text { (non- } \\
\text { significan } \\
\text { t) }\end{array}$ & 468.483 & 4.339 & Good \\
\hline $\begin{array}{l}\text { Significance } \\
\text { Probability (p) }\end{array}$ & $\geq 0.05$ & 0.000 & 0.114 & $\begin{array}{l}\text { Suitabl } \\
\text { e }\end{array}$ \\
\hline $\begin{array}{l}\text { Practical indices of fit: } \\
\text { Normed chi-square } \\
\text { (CMIN) }(\chi 2 / d f) \\
\text { Absolute fit index: }\end{array}$ & $\leq 2.0$ & 31.232 & 2.170 & $\begin{array}{l}\text { Suitabl } \\
\text { e }\end{array}$ \\
\hline $\begin{array}{l}\text { Goodness of Fit Index } \\
\text { (GFI) }\end{array}$ & $\geq 0.9$ & 0.657 & 0.996 & $\begin{array}{l}\text { Suitabl } \\
\mathrm{e}\end{array}$ \\
\hline $\begin{array}{ll}\text { Adjusted } & \text { Goodness } \\
\text { Fit of Index } & \text { (AGFI) }\end{array}$ & $\geq 0.9$ & 0.360 & 0.943 & $\begin{array}{l}\text { Suitabl } \\
\text { e }\end{array}$ \\
\hline $\begin{array}{l}\text { Root Mean Square } \\
\text { Error } \\
\text { Approximation } \\
\text { (RMSEA) } \\
\text { Incremental fit indices: }\end{array}$ & $\leq 0.08$ & 0.318 & 0.063 & $\begin{array}{l}\text { Suitabl } \\
\mathrm{e}\end{array}$ \\
\hline $\begin{array}{l}\text { Normed } \\
\text { (NFI) }\end{array}$ & $\geq 0.90$ & 0.000 & 1.00 & $\begin{array}{l}\text { Very } \\
\text { Suitabl } \\
\text { e }\end{array}$ \\
\hline $\begin{array}{l}\text { Comparative Fit Index } \\
(\mathrm{CFI})\end{array}$ & $\geq 0.9$ & 0.233 & 0.996 & $\begin{array}{l}\text { Very } \\
\text { Suitabl } \\
\text { e }\end{array}$ \\
\hline $\begin{array}{l}\text { Tucker Lewis Index } \\
\text { (TLI) }\end{array}$ & $\geq 0.9$ & -0.074 & 0.958 & $\begin{array}{l}\text { Very } \\
\text { Suitabl } \\
\text { e }\end{array}$ \\
\hline
\end{tabular}




\subsection{Hypothesis Test Results}

The data analysis of hypothesis test seen from the size significance of regression weight model is shown in Table 2.

Table 2. Regression Weights

\begin{tabular}{lllll}
\hline $\begin{array}{l}\text { Vari } \\
\text { able }\end{array}$ & $\begin{array}{l}\text { Estim } \\
\text { ation }\end{array}$ & $\begin{array}{l}\text { Error } \\
\text { Standar } \\
\text { d }\end{array}$ & $\begin{array}{l}\text { Critical } \\
\text { Ratio }\end{array}$ & $\begin{array}{l}\text { Proba } \\
\text { bility }\end{array}$ \\
\hline$(2)$ & $(3)$ & $(4)$ & $(5)$ & $(6)$ \\
$\mathrm{X} 1$ & -0.011 & 0.079 & -0.134 & 0.894 \\
$\mathrm{X} 2$ & 0.422 & 0.049 & 8.538 & 0.000 \\
$\mathrm{X} 3$ & 0.180 & 0.057 & 3.167 & 0.002 \\
$\mathrm{X} 4$ & 0.100 & 0.025 & 3.998 & 0.000 \\
$\mathrm{X} 5$ & -0.032 & 0.068 & -0.476 & 0.634 \\
\hline
\end{tabular}

Based on the calculation results in Table 2, it can be explained that:

a. The significance test of hypothesis 1 is not significant with probability value 0.894 .

b. The significance test of hypothesis 2 is significant with probability value 0.000 .

c. The significant test of hypothesis 3 is significant with probability value 0.002 .

d. Test of significance to hypothesis 4 significant with probability value 0.000 .

e. The significance test of hypothesis 5 is not significant with probability value 0.634 .

\subsection{Results of Factor Analysis}

The result of factor analysis of the effect of running speed, leg muscle strength, arm muscle strength and balance to the achievement of vault technique can be seen from standardized regression weight analysis in Table 3.

Table 3. Results of Factor Analysis

\begin{tabular}{|c|c|c|c|c|}
\hline $\begin{array}{l}\text { Var } \\
\text { iabl } \\
\text { e }\end{array}$ & $\begin{array}{l}\text { Estim } \\
\text { ation }\end{array}$ & $\begin{array}{l}\text { Probab } \\
\text { ilities }\end{array}$ & Significe & $\begin{array}{l}\text { Category } \\
\text { of } \\
\text { Relation }\end{array}$ \\
\hline (2) & (3) & (4) & & ) \\
\hline $\mathrm{X} 1$ & -0.009 & 0.894 & $\begin{array}{l}\text { Insignifican } \\
\mathrm{t}\end{array}$ & $\begin{array}{l}\text { Very } \\
\text { weak }\end{array}$ \\
\hline $\mathrm{X} 2$ & 0.454 & 0.000 & Significant & Medium \\
\hline X3 & 0.169 & 0.002 & Sign & Weak \\
\hline X4 & 0.206 & 0.000 & Significant & Weak \\
\hline $\mathrm{X} 5$ & -0.029 & 0.634 & $\begin{array}{l}\text { Insignifican } \\
\mathrm{t}\end{array}$ & $\begin{array}{l}\text { Very } \\
\text { weak }\end{array}$ \\
\hline
\end{tabular}

Source: Output Results of SPSS AMOS 22.0 (2017)
Based on the result of factor analysis in Table 3, the influence of direct relationship $(\lambda)$ between physical ability (X) to the performance variable of vault technique $(\mathrm{Y})$ is as follows:

a. Influence $(\lambda)=\mathrm{X}_{1} \rightarrow \mathrm{Y}:(\mathrm{r}=0.894$, $\mathrm{p}<0.01)$ with correlation value -0.009 .

b. Influence $(\lambda)=X_{2} \rightarrow Y:(r=0.000, p<$ $0.01)$ with correlation value 0.454 .

c. Influence $(\lambda)=X_{3} \rightarrow Y:(r=0.002, p<$ $0.01)$ with correlation value 0.169 .

d. Influence $(\lambda)=X_{4} \rightarrow Y:(r=0.000, p<$ $0.01)$ with correlation value 0.206 .

e. Influence $(\lambda)=X_{5} \rightarrow Y:(r=0.634$, $\mathrm{p}<0.01)$ with correlation value -0.029 .

\section{Discussion}

The first hypothesis test on run speed factor on the achievement of vault technique was not significant $(\mathrm{r}=0.894, \mathrm{p}<0.01)$. The effect $(\lambda)=\mathrm{X} 1 \rightarrow \mathrm{Y}$ belongs to a very weak category and has a very insignificant effect on the correlation value -0.009 . The common mistake that occurs in the stage of the run-up is when the gymnast waits for a few seconds to take into account the steps to be taken. The difference in running speed on the long jump and the vault is the further motion. The long jumper uses run-up for take-off and moves his body weight straight ahead while the gymnast uses a limited run-up to find a good angle when take-off to the first flight phase. The results of this study are partially consistent with the findings of Linthorne and Weetman's research (2012) stating that excessive run-up speeds cause energy losses at take-off, and the thing to do at run-up is reducing the strength of the transmitted reaction to the upper limb in phase round-off of the vault.

Testing of the second hypothesis on leg muscle strength factor to the achievement of vault technique obtained the significant result $(\mathrm{r}=0.000, \mathrm{p}<0.01)$. Influence $(\lambda)=\mathrm{X} 2 \rightarrow \mathrm{Y}$ belongs to the medium category and has the most significant influence on correlation value 0.454 . The movement of the lower extremities while running up to the round-off position and landing point of the fulcrum culminates in the leg muscle strength. Leg muscle strength contributes to the strength of foot jumps. The maximal explosive muscle strength provides good acceleration capability. The results of other studies are highly relevant to Kim et al., (2010) showing that the lower-limb muscle 
inferior motion affects the maximal anteriorsuperior at the time of hyoid and larynx displacement and has a significant association with the oesophageal sphincter. The lower limbs support the superior parts: neck, head, and torso.

The third hypothesis testing on the strength factor of arm muscle to the achievement of vault technique obtained the significant result $(\mathrm{r}=0.002, \mathrm{p}<0.01)$. The effect $(\lambda)=\mathrm{X} 3 \rightarrow \mathrm{Y}$ belongs to the weak category and has a significant influence on the correlation value of 0.169 . Horizontal and vertical velocities decrease at the time of contact between the palms of the hand with the table. Therefore, it is necessary to maintain the angle of the upper limb momentum and hold the lower leg angle. The results of research by Peixoto dos Santos (2017) showed that arm muscle strength contributes to the dominant upper extremity motion pattern. Motoshima and Maeda (2015) arm muscle acts as the stability of the position of the body because of the maximum suspicion of triceps brachii (TB), pectotralis major (PM), serratus anterior (SA), and posterior deltoid (PD).

Testing of the fourth hypothesis on abdominal muscle strength factor to the achievement of vault technique obtained the significant result $(\mathrm{r}=0,000, \mathrm{p}<0,01)$. Influence $(\lambda)=(\mathrm{X} 4 \rightarrow \mathrm{Y})$ is weak, and has a significant influence on correlation value 0.206. The maximum leap movement in gymnasts is strongly influenced by the performance of the abdominal muscle wall and the muscles that span between the pelvic bracelet and the chest cavity and acts as a leg muscle and shoulder muscle stabilizer. The results of this study are highly relevant to research conducted by Rameshkannan and Chitibabu (2014) stating that abdominal muscle strength plays a vital role in hand manipulative motion. Narimo et al., (2013) showed that the strength of abdominal flexion is significantly correlated to the abdominal recess, and internal oblique muscle, and causes strong pressure on predominant intervertebral discs along the lumbar spine.

The fifth hypothesis test on balancing factor on the achievement of vault technique was not significant $(\mathrm{r}=0.634, \mathrm{p}<0.01)$. Influence $(\lambda)=\mathrm{X} 5 \rightarrow \mathrm{Y}$ category is very weak and has no significant effect on correlation value -0.209 . The balance of landing is affected by the complexity of the initial rotation, linear velocity, and the air angle phase. The equilibrium in the jump table uses minimal muscle activity because the average gymnastics only takes under 4 seconds. The results of this study did not match the research of Leonardo (2011) stating that balance is contributing positively to the postural performance of motion sensory of static and dynamic motors, and is correlated significantly at landing.

The results of research and discussion revealed that the most dominant factor to give effect is leg muscle strength, while the smallest influence is in the running speed factor. Thus, this research can be used as a theoretical foundation to improve the training program for trainers, teacher, athletes, and student. In the future, research of factor analysis that covers all disciplines and tools of the olympic gymnastics is required.

\section{References}

Akhtaruzzaman, A. Shafie, A. \& A. Khan, M. R. (2016). A Review of Lower Appendicular Musculoskeletal System of Human Body. International Islamic University Malaysia Engineering Journal, 17(1), 83-102.

Alves, C. R. R. Borelli, M. T. C. Vitor, P. Azevedo, S. R. A. Borelli, C. C. G. Junior, A. H. L. Gualano, B. \& Artioli, G. G. (2015). Development of a Specific Anaerobic Field Test for Aerobic Gymnastics. PLOS ONE, 10(4), 1-10.

Atiković, A. (2012). New Regression Models to Evaluate the Relationship between Biomechanics of Gymnastic Vault and Initial Vault Difficulty. Journal of Human Kinetics, 35(1), 119-126.

Calatayud, J. Borreani, S. Colado, J. C. Martin, F. Batalha, N. \& Silva, A. (2014). Muscle Activation Differences Between Stable Push-Ups and Push-Ups With A Unilateral V-Shaped Suspension System at Different Heights. Motricidade, 10(4), 84-93.

Kim, S. J. Han, T. R. Jeong, S. J. \& Beom, J. W. (2010). Comparison Between Swallowing-Related and Limb Muscle Involvement in Dermatomyositis Patients. Scandinavian Journal of Rheumatology, 39(4), 336-340.

Kochanowicz, A. Kochanowicz, K. Niespodziński, B. Mieszkowski, J. Aschenbrenner, P. B. G. \& Szark- 
Eckardt, M. (2016). Maximal Power of the Lower Limbs of Youth Gymnasts and Biomechanical Indicators of the Forward Handspring Vault Versus the Sports Result. Journal of Human Kinetics, 53(1), 33-40.

Leonardo, R. (2011). Static and Dynamic Balance in Young Athletes. Journal of Human Sport Science, 6 (4): 616-628.

Linthorne, N. P. \& Weetman, A. H. G. (2012). Effects of Run-Up Velocity on Performance, Kinematics, and Energy Exchanges In The Pole Vault. Journal of Sports Science and Medicine, 11(2), 245-254.

Mariana, F. Octavian, V. Daniela, C. \& Iliana, V. (2016). Music and The Artistic Rhythm-Psychosomatic Implications. Science, Movement and Health, 16(1), 126-130.

Motoshima, Y. \& Maeda, A. (2015). Kasamatsu Versus Tsukahara Vault. Science of Gymnastics Journal, 7(2), 1524.

Narimo, Kabul. Sugiharto. \& Waluyo, Musyawari. (2013). Sumbangan Power Lengan, Togok dan Tungkai Terhadap Kemampuan Servis Atas Bolavoli. Journal of Sport Sciences and Fitness, 2(2), 44-48.

Pavlova, I. Vynogradskyi, B. Kurchaba, T. \& Zikrach, D. (2017). Influence of
Leisure-Time Physical Activity on Quality of Life of Ukrainian Students. Journal of Physical Education and Sport, 17(3), 1037-1042.

Peixoto dos Santos, S. Benda, R. N. Couto, E. C. Andrade, C. R. C. Lage, A. G. P. G. M. \& Ugrinowitsch, H. (2017). The Level of Performance Stabilization Influences Motor Adaptation on an Isometric Force Control Task. PLOS ONE, 12(10), 1-4.

Rameshkannan, S. \& Chittibabu, B. (2014). Comparison of Abdominal Strength Endurance Between Handball and Volleyball Players. International Journal for Life Sciences and Educational Research, 2(4), 129-130.

Subekti, Nur. Kristiyanto, Agus. \& Purnama, Sapta Kunta. (2014). Kemampuan Tendangan Sabit Mahasiswa Pembinaan Prestasi Pencak Silat Uns Surakarta Ditinjau Dari Koordinasi Mata-Kaki Kecepatan Rasio Panjang Tungkai Dan Tinggi Badan. Indonesian Journal of Sports Science, 1(1), 1-14.

Ugulu, I. (2013). Confirmatory Factor Analysis for Testing Validity and Reliability of Traditional Knowledge Scale to Measure University Students' Attitudes. Educational Research and Reviews, $\quad 8(16), \quad$ 1399-1408. 